\title{
AUTUMN OVERDRILLING OF LUCERNE WITH CEREALS AND ANNUAL RYEGRASSES TO IMPROVE SPRING PRODUCTION IN SOUTH CANTERBURY AND NORTH OTAGO
}

\author{
C. C. MCLEOD
}

Soil and Field Research Organisation, MAF, Tirnaru

J. A. Douglas

Ruakura Agricultural Research Centre, Hamilton

\section{Abstract}

Six trials were conducted in 1966-68 in which four cereals and two annual ryegrasses were overdrilled into lucerne in the autumn. Cereals were more productive than annual ryegrasses when left uncut until the spring. Nitrogen fertilizer improved the growth of the overdrilled species but also stimulated weed growth where there was inadequate competition from the overdrilled species. To make best use of the productive potential of the overdrilled cereals they should remain ungrazed from sowing until early to mid-spring, but this clearly has to be weighed against other management factors.

\section{INTRODUCTION}

THE imbalance of lucerne production between summer and winter/early spring periods is well known in New Zealand and four ways of lessening this difference have been investigated.

(1) Improved cultivar production (Palmer, 1959).

(2) Autumn management of stands (Douglas, 1971; Janson, 1975).

(3) Lucerne/perennial grass mixtures (O’Connor, 1967; Cullen, 1967).

(4) Overdrilled annual grasses and cereals in autumn.

This last method has been used for many years in New Zealand but few experimental data have been reported. In the 1920s and 1930s a widespread practice was to sow oats in April into lucerne stands cultivated to control weeds (Anon., 1931; Davies, 1938). A later modification of this technique was to use 'Grasslands Manawa' ryegrass instead of oats (Taylor, 1953). More recently Vartha (1967, 1971) has given evidence that overdrilling annual ryegrasses improved winter production and such a technique has 
TABLE 2: TRIAL 1, WAITAKI -TOTAL HERBAGE PRODUCTION AT THREE HARVEST DATES (kg/ha DM; \% weeds in parentheses)

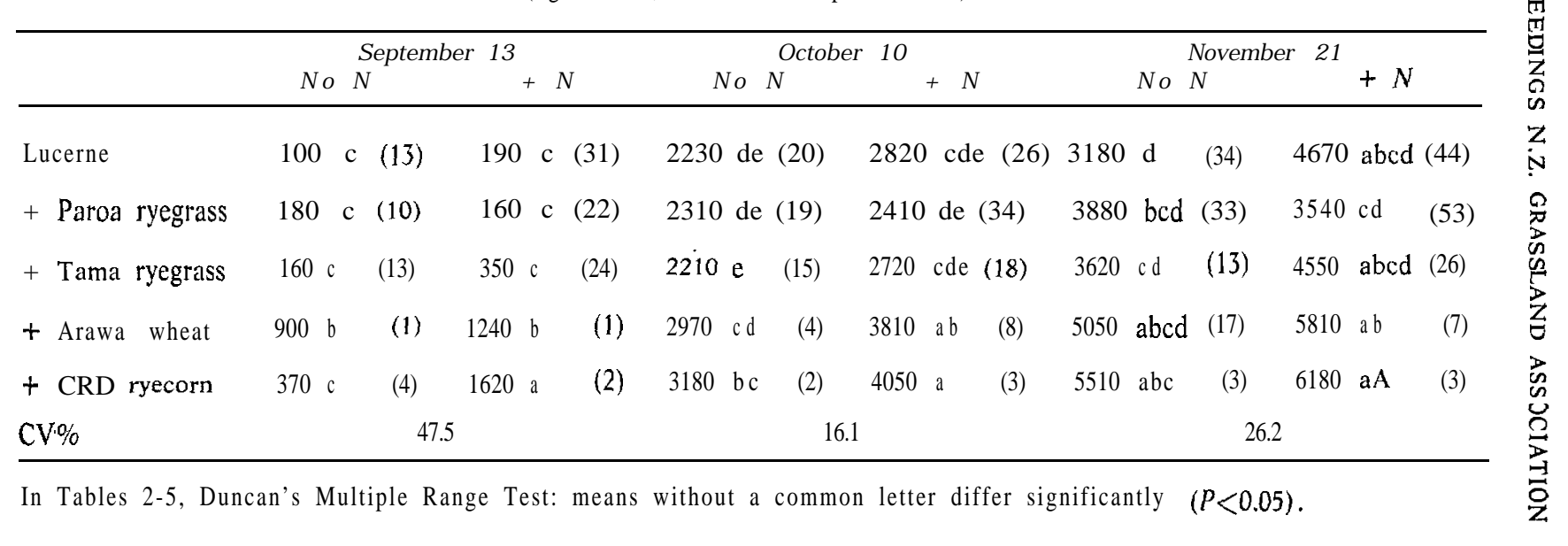


been adopted on light land in Canterbury (Stewart, 1970) $\%$ On the other hand, Janson (1975) found 'Grasslands Tama' Wésterwolds ryegrass useful only when irrigation was applied to improve its establishment, and Hoglund (1972) found that, while Tama ryegrass improved early spring yields under irrigation, it suppressed subsequent lucerne growth. Overdrilled cereals, thave received less attention. O'Connor (1967) showed that overdrilled wheat gave increased spring production, but Vartha (1967) obtained no additional benefit from mixing oats with an annual ryegrass because the oats gave negligible production after the first winter grazing.

The series of trials reported here was conducted in North Otago and South Canterbury to investigate further the effects of attumn overdrilling of cereals and annual ryegrasses into established dryland lucerne stands on late winter/early spring and late spring/ carly summer forage yields.

\section{METHOD}

Six trials were conducted, four in North Otago and two in South Canterbury (Table 1),

TABLE 1: TRIAL SITE DETAIL AND DATE OF OVERDRILLINGG

\begin{tabular}{cllc}
\hline Site & Location & Soil Type & Date Overdrilled \\
\hline 1 & Waitaki & Waimakariri & 31.3 .67 \\
2 & Windsor & Timaru & 4.4 .68 \\
3 & Omarama & Grampian & 21.3 .67 \\
4 & Omarama & Grampian & 21.3 .68 \\
5 & Studholme & Claremont & 1.3 .66 \\
6 & Rosewill & Timaru & 20.3 .68 \\
\hline
\end{tabular}

In three North Otago trials (Nos. 1, 2, 4) the different species were direct-drilled using a hoe coulter drill after the sites had been cultivated one way with a chisel tine cultivator. In the remaining three trials no prior cultivation was carried out.

Plots were single drill strips 20 to $40 \mathrm{~m}$ long with 3 to 6 replicates, and these remained ungrazed over the winter/early spring period.

Treatments included $130 \mathrm{~kg} / \mathrm{ha}$ Arawa or Hilgendorf wheat, $130 \mathrm{~kg} / \mathrm{ha}$ CRD ryecorn, 110 to $130 \mathrm{~kg} / \mathrm{ha}$ Winter Grey or Amuri oats, $110 \mathrm{~kg} / \mathrm{ha}$ Carlsberg or Kakapo barley, $20 \mathrm{~kg} / \mathrm{ha}$ 'Grasslands Paroa' and $30 \mathrm{~kg} / \mathrm{ha}$ Tama ryegrass. All trials were drilled with basal superphosphate (125 to $250 \mathrm{~kg} / \mathrm{ha})$ and had nitrogen $(125$ 
to $250 \mathrm{~kg}$ /ha nitrolime) applied either as a basal or as a treatment. In North Otago all nitrogen was drilled with the seed, whereas in South Canterbury it was topdressed soon after drilling.

Production measurements were made with a sickle-bar mower with samples dissected to determine the percentage contribution of the various species.

\section{RESULTS}

\section{TrIAL 1: WAITAKI}

Production cuts to measure the uninterrupted growth from sowing were made on September 13, October 10 and November 21 (Table 2).

In September when lucerne growth had just begun, there was already good production from the overdrilled cereals, particularly where nitrogen had been applied. The later cuts showed substantial increases in production by leaving the cereals, in particular, to shoot to ear, the final cut being made when the cereals were in flower.

The ryegrasses added little to the spring production, this probably being due to the exceptionally dry winter.

Nitrogen fertilizer enhanced the production of the overdrilled species but it also stimulated weed growth, especially in the ryegrass plots which were not as vigorous as the cereals (Table 2). The overdrilled cereals successfully controlled weeds, which were dominantly barren brome (Bromus sferilis), barley grass (H ordeum murinum) and shepherd's purse (Capsella hursa-pasforis) .

\section{TRIAL 2: WINDSOR}

Production cuts to measure the uninterrupted growth from sowing were made on September 30 and November 4 (Table 3).

The overdrilled species improved production substantially at both cuts with the cereals being higher producing than the annual ryegrasses. As with cereals in Trial 1 , the overdrilled species effectively controlled weed growth.

\section{Trials 3 AND 4: OMARAMa}

Production cuts from these two trials are given in Table 4.

In this colder environment the overdrilled species gave little production before the lucerne began to grow. In 1967 the treatments sown with a grassland sod seeder direct into the lucerne stand gave little improvement in production, with the ryegrasses 
TABLE 3: TRJAL 2, WINDSOR- TOTAL HERBAGE PRODUCTION AT TWO HARVEST DATES

( $\mathrm{kg} / \mathrm{ha} \mathrm{DM} ; \%$ weeds in parentheses)

\begin{tabular}{lcc}
\hline & Sep. 30 & Nov. 4 \\
\hline Lucerne & $1460 \mathrm{~d}$ & $3710 \mathrm{~d} \quad(25)$ \\
+ Tama ryegrass & $2520 \mathrm{~b}$ & $4470 \mathrm{c} \mathrm{(4)}$ \\
+ Paroa ryegrass & $2070 \mathrm{c}$ & $4130 \mathrm{~cd}(9)$ \\
+ Arawa wheat & $3190 \mathrm{a}$ & $5580 \mathrm{ab}(4)$ \\
+ CRD ryecorn & $3100 \mathrm{a}$ & $5910 \mathrm{a}(2)$ \\
+ Winter Grey oats & $3000 \mathrm{a}$ & $5370 \mathrm{~b}(2)$ \\
cv $\%$ & 11.4 & 7.3 \\
\hline
\end{tabular}

TABLE 4: TRIALS 3 AND 4, OMARAMA-TOTAL HERBAGE PRODUCTJON AT SINGLE HARVEST DATES $(\mathrm{kg} / \mathrm{ha} \mathrm{DM})$

\begin{tabular}{lcc}
\hline & Trial 3 & Trial 4 \\
Oct. 17 & N ov. 5 \\
\hline Lucerne & $2300 \mathrm{~b}$ & $2740 \mathrm{~b}$ \\
+ Tama ryegrass & $2530 \mathrm{ab}$ & $2750 \mathrm{~b}$ \\
+ Paroa ryegrass & $2830 \mathrm{a}$ & $2830 \mathrm{~b}$ \\
+ Arawa wheat & $2770 \mathrm{a}$ & $3720 \mathrm{a}$ \\
+ CRD ryecorn & $2680 \mathrm{a}$ & $3670 \mathrm{a}$ \\
+ Winter Grey oats & - & $2950 \mathrm{~b}$ \\
cv \% & 14.5 & 13.3 \\
\hline
\end{tabular}

TABLE 5: TRIAL 5, ROSEWILL PRODUCTION OF LUCERNE AND OVERDRILLED RYEGRASSES AND \% WEEDS ( $\mathrm{kg} / \mathrm{ha} \mathrm{DM})$

\begin{tabular}{|c|c|c|c|c|}
\hline Cut & Lucerne & R yegrass & Total & $\%$.Weeds \\
\hline \multicolumn{5}{|l|}{ June 11: } \\
\hline Lucerne & 590 a & - & $1040 \mathrm{c}$ & 43 \\
\hline + Tama & $690 \mathrm{a}$ & 690 a & 1520 a & 8 \\
\hline+ Paroa & 720 a & $450 \mathrm{~b}$ & $1380 \mathrm{~b}$ & 15 \\
\hline \multicolumn{5}{|l|}{ Sep 30: } \\
\hline Lucerne & $1100 \mathrm{a}$ & - & $2160 \mathrm{c}$ & 49 \\
\hline + Tama & $1050 \mathrm{a}$ & $2690 \mathrm{a}$ & 3890 a & 4 \\
\hline + Paroa & $990 \mathrm{a}$ & $2170 \mathrm{a}$ & $3370 \mathrm{~b}$ & 6 \\
\hline \multicolumn{5}{|l|}{ Nov 7: } \\
\hline Lucerne & $710 \mathrm{a}$ & - & 1850 a & 62 \\
\hline + Tama & $410 \mathrm{~b}$ & $1370 \mathrm{a}$ & 1830 a & 2 \\
\hline+ Paroa & $560 \mathrm{ab}$ & $1340 \mathrm{a}$ & 1980 a & 4 \\
\hline \multicolumn{5}{|l|}{ Total: } \\
\hline Lucerne & $2400 \mathrm{a}$ & - & $5050 \mathrm{c}$ & 52 \\
\hline + Tama & $2150 \mathrm{a}$ & $4750 \mathrm{a}$ & $7240 \mathrm{a}$ & 5 \\
\hline + Paroa & $2270 \mathrm{a}$ & $3960 \mathrm{~b}$ & $6730 \mathrm{~b}$ & 8 \\
\hline
\end{tabular}


contributing $4 \%$ to the yield and the cereals $15 \%$. In 1968, spring production was increased by the ryecorn and wheat treatments but not by the other overdrilled species. In this year snow lay for 4 to 6 weeks and these severe conditions caused considerable plant mortality, particularly in Tama ryegrass and oats.

\section{Trial 5: StUdholme}

In this trial overdrilled oats had increased production by $44 \%$ (1340 kg/ha) on April 12 but overdrilled wheat, barley, and annual ryegrass had no effect. Following a dry winter no treatments gave increased production.

\section{TRIAL 6: ROSEWILL}

The production from a cut and recut system of the ryegrass treatments with additional nitrogen fertilizer is shown in Table 5.

The ryegrasses with nitrogen fertilizer added between 33 and $43 \%$ to total production with the nitrogen fertilizer improving ryegrass growth by $35 \%$ at the first two cuts but giving no improvement in the final harvest.

The Tama ryegrass outproduced the Paroa ryegrass, this mainly being due to the better late autumn and winter production of Tama rather than its early spring production.

The overdrilled ryegrasses suppressed the grass weeds present (Poa annua, Lolium perenne) .

\section{DISCUSSION}

The trials in coastal North Otago show that large gains in production can be obtained by overdrilling various cereals into lucerne in the autumn when they are not cut or grazed until the early spring. Earlier defoliation as in the trial at Studholme, and from the results of Vartha (1967) and Baars and Douglas (1976), show that regrowth of cereals may be limited. This indicates that an essential point in the management of overdrilled cereals is that they should be looked upon as single harvest crops with the timing of their grazing being in early spring when they are growing more quickly than the lucerne. This is illustrated in the trial at Waitaki where from the date of overdrilling to early September the lucerne made negligible growth $(0.5 \mathrm{~kg} / \mathrm{ha} /$ day $)$ while the ryecorn and nitrogen treatment grew at $9.5 \mathrm{~kg} / \mathrm{ha} /$ day. In the September to October period when the lucerne grew at $62 \mathrm{~kg} / \mathrm{ha} /$ day (excluding weeds) the ryecorn mixture grew at $87 \mathrm{~kg} / \mathrm{ha} /$ day. By using a 
break-grazing system in August or September, the overdrilled cereals would be allowed to continue their rapid build-up of dry matter in front of the break-fed animals.

The North Otago trials showed that cereals could also be used to give large increases in hay or silage yields in October and November in agreement with pre-war experience (Anon., 1931; Davies, 1938). In inland North Otago where cold winter conditions prevent early growth of the cereals, this use of the overdrilled cereals appears feasible although further information is required.

The productive ability of the cereals appeared similar under the infrequent cutting system. However, in the Waitaki trial, ryecorn seemed more sensitive than wheat to low nitrogen conditions over the winter period, and at Omarama oats were less cold-tolerant than wheat or ryecorn. The choice of cereal becomes more difficult if one is required with good regrowth potential to allow regular grazing. While further work is required, generally wheat and ryecorn have better regrowth characteristics than barley or oats.

The annual ryegrasses performed poorly under dry conditions in South Canterbury and North Otago in 1966 and 1967 but they showed better growth in 1968 when wetter conditions occurred. Both Janson (1975) and Vartha (1971) found that Tama ryegrass gave poor winter and early spring production if dry autumn conditions prevented rapid germination and establishment. However, if adequate soil moisture was present, early autumn establishment of ryegrass improved its winter production (Vartha, 1971). On the other hand, early autumn sowings of cereals may be infected with barley yellow dwarf virus.

The ryegrasses suit a regular winter grazing system but their persistence into the late spring and early summer can depress lucerne growth (Baars and Douglas, 1976). Janson (1975) has shown that grazing of lucerne in winter lowers the subsequent spring production. Therefore, any gain from overdrilled annual ryegrasses which are grazed regularly throughout the winter has to be equated against the later reduction of lucerne. In addition, while a single spring grazing is less harmful to the lucerne than a number of winter grazings (Vartha, 1971), early spring defoliation can reduce yields more than late spring defoliation (Vartha, 1967).

Nitrogen fertilizer was beneficial to the overdrilled species in agreement with the results of Vartha (1967) although good cereal production was obtained without nitrogen in the Waitaki trial. Nitrogen did, however, increase the weed content of the lucerne if there was inadequate competition from the overdrilled species. 
The lack of success of the trial at Studholme is difficult to put down solely to dry conditions since there was $74 \mathrm{~mm}$ more rainfall over the March to August period than the $184 \mathrm{~mm}$ recorded at the successful Waitaki site. One point of difference was that the Waitaki trial had a light cultivation with a chisel tine cultivator prior to drilling, while the Studholme trial was disc-drilled directly into the sward. Vartha (1967) has reported some improvement in the production of species overdrilled following a surface cultivation and the importance of this point requires further investigation..

\section{CONCLUSION}

These trials have indicated that the winter and spring production of lucerne stands can be improved by autumn overdrilling cereals and annual ryegrasses. However, while the short term gains arc evident, recent trial work (e.g., Janson, 1975) show a complex situation exists in which the yield of the overdrilled species and the accompanying depression of lucerne by competition and winter and spring grazing all have to be considered in relation to annual lucerne management. Consequently, further information is required from trials run over several years to obtain a greater understandiing of the benefits and pitfalls of autumn overdrilling of lucerne stands.

\section{ACKNOWLEDGEMENTS}

The co-operation of farmers on whose properties the trials were conducted and the technical and biometrical assistance from Ministry of Agriculture and Fisheries personnel are gratefully acknowledged.

\section{REFERENCES}

Anon., 1931. Lucerne on the farm. Culture and management under New Zealand conditions. N.Z. Jl Agric. 43: 155-71.

Baars, J. A.; Douglas, J. A., 1976. Autumn overdrilled Tama ryegrass and cereals to supplement lucerne in the Central North Island. Proc. N.Z. Grassld Ass., 37: 237.

Cullen, N. A., 1967. Establishment and management of lucerne grass mixlures. In The Lucerne Crop (ed. R. H. M. Langer), pp. 186-9. Reed, Wellington.

Davies, J.E., 1938. Autumn-sown oats with lucerne. N.Z. Jl Agric., 57: 443.

Douglas, J. A., 1971. Autumn-lucerne management-effect on early spring production. N.Z. agric. Sci., 6 (2): 13-5.

Hoglund, J. H., 1972. Effect of defoliation management and 'Tama' overdrilling on weed yields of irrigated lucerne. Proc. N.Z. Weed \& Pest Control Conf., 25: 96-100. 
Janson, C. G., 1975. Influence of autumn-winter lucerne management and overdrilled 'Grasslands Tama' on spring herbage yields under irrigated and dry conditions. N.Z. $/ l$ exp. Agric., 3: 229-34.

O'Connor, K. F., 1967. Lucerne-grass association under different sowing and defoliation systems. In The Lucerne Crop (ed. R. H. M. Langer), pp. 163-75. Reed, Wellington.

Palmer, T. P., 1959. Winter growth of lucerne (Medicago saiva). I. Variety performance in New Zealand. N.Z. /l agric. Res., 2: 1195-1202.

Stewart, J. D., 1970. The intensive use of light land. Proc. N.z. Grassld Ass., 32: $198-205$.

Taylor, C. R., 1953. Oversowing lucerne with short rotation ryegrass. N.Z. Il Agric., 87: 425-6.

Vartha, E. W., 1967. Lucerne overdrilled with grasses for grazing. In The Lucerne Crop (ed. R. H. M. Langer), pp. 177435. Reed, Wellington. 1971 . Overdrilled winter-growing annual grass to supplement lucerne. Proc. N.Z. Grassld Ass., 33: 115-23. 